\title{
COMMENTARY
}

\section{THE JUDICIARY AND SUSTAINABLE DEVELOPIMNT: PERSPECTIVES OF A BRAZILIAN FEDERAL JUDGE}

\author{
Gabriel Wedy*
}

\begin{abstract}
The approval of 17 goals and 169 targets for sustainable development by the United Nations Conference on Post-2015 Development Agenda is unquestionably an advancement for humanity. Economic development alone is however unsatisfactory: it must be paired with human development, respect for the environment and sound governance. Drawing from litigation and jurisprudential development from the Brazilian judiciary, this short legal commentary evaluates the role of the judiciary in promoting sustainable development, especially the attainment of the United Nations Sustainable Development Goals (SDGs).
\end{abstract}

Keywords: Brazil, Sustainable Development, Judiciary.

doi: http://dx.doi.org/10.4314/jsdlp.v6i2.10

\section{INTRODUCTION}

Brazil is undoubtedly a classic example of global unsustainability. Although it is the ninth largest economy in the world in terms of Gross Domestic Product (GDP), it occupies the 79th position in the global ranking of human development and it is in the 60th position in the world ranking of education. ${ }^{1}$ It has the 71st position in gender equality. According to the world poverty ranking measured by the Gini index, Brazil is the 17th most unequal country

* Federal Judge in Brazil, an Environmental Law Professor at ESMAFE/RS (the Federal Judiciary Superior School) and a Visiting Scholar at Columbia Law School(Sabin Center for Climate Change Law).

1 United Nations, Human Development Report 2014. Source: United Nations<http: hdr.undp.org>accessed11 November 2015. 
in the G-20 and the 14th poorest country in the world. ${ }^{2}$ Lastly, Brazil occupies the 77th position in the world ranking of general sustainability and the 115th position in the category of forest protection, according to the Environmental Performance Index of Yale University in $2014 .^{3}$

The country has presented a pledge to the United Nations (UN) to slash its greenhouse emissions by 43 per cent, which is commendable, but difficult to achieve. ${ }^{4}$ There is a lack of capacity to monitor all of the vast Amazon forest, which is needed to help avoid its rampant deforestation. Public and private means of transportation use fossil fuels. Wind and solar power plants are still not very significant. There is no planning for the creation of sustainable infrastructure in public and private works. Brazil lacks a consistent programme for energy conservation and efficiency. The government has no system to monitor emissions. Furthermore, Brazil is far from implementing a system such as a carbon tax or cap and trade to reduce emissions of greenhouse gases.

There are also serious problems affecting governance. Recently, two large corruption schemes erupted: the case called "Mensalão", in which bribes were paid to politicians to finance election campaigns, and the "Operation Car Wash" which brought to light the diversion of large sums of public money from the state-owned oil company "Petrobrás". ${ }^{5}$ In 2013, thousands of Brazilians took to the streets to protest against the politicians and the lack of sound public policies. More recently, people took to the streets and the Congress opened impeachment procedure against President Dilma Rousseff. ${ }^{6}$

Poor public policies and corruption itself are evidently not news: they are afflictions that have haunted the country from the time Brazil was a colony of

2 Organisation for Economic Co-operation and Development $<$ www.oecd.org $>$ accessed 20 September 2015.

3 Yale University, Environmental Performance Index Yale <http://epi.yale.edu/ $>$ accessed 4 April 2016.

4 "Brazil pledges to cut carbon emissions $37 \%$ by 2025 and $43 \%$ by 2030 "The Guardian < www. theguardian.com/environment/2015/sep/28/brazil-pledgesto-cut-carbon-emissions-37-by-2025>accessed 30 October 2015

5 David Segal, "Petrobras Oil Scandal Leaves Brazilian Lamenting a Lost Dream" The New York Times(7 April 2015) < www.nytimes.com/2015/08/09/business/ international/effects-of-petrobras-scandal-leave-brazilians-lamenting-a-lostdream.html>accessed 20 April 2016.

6 Andrew Jacobs, "Brazil's Lower House of Congress Votes for Impeachment of Dilma Rousseff"The New York Times (17 April 2016) < www.nytimes.com/2016/ 04/18/world/a mericas/brazil-dilma-rousseff-impeachment vote.html>accessed24 April 2016. 
the Portuguese empire. The search for sustainable development is not the responsibility of the executive and legislative arms alone. The judiciary, as trusted gatekeeper and protector of fundamental rights and freedoms, also has eminent roles to play in facilitating environmental protection and sustainability. The pertinent question therefore is, in the extant scenario of unsustainable development, how have the Brazilian courts been resolving their cases?

\section{ROLES OF JUDGES}

Through their decisions, judges have guaranteed Brazilian citizens important rights which are stated in the progressive Constitution of 1988, drawn up after 20 years of military dictatorship. The citizen's rights to medical treatment, medicine, surgery, housing and access to education are frequently guaranteed by judicial decisions.

The Brazilian Constitution also protects the environment. Article 225 provides that "... everyone has the right to an ecologically balanced environment, which is an asset of common use of the people and essential to a healthy quality of life, imposing on the Public Power and the community the duty to defend it and preserve it for the present and future generations". ${ }^{7}$ Recent precedents have shown that judges have taken this right seriously. The Judicial Branch, by applying the precautionary principle, ${ }^{8}$ has prevented a great deal of environmental damage as well as the deforestation of the Brazilian Amazon rainforest. Several decisions prevent construction projects and the emission of substances that pollute water and soil and threaten the animals, plants or human health. When it comes to legal proceedings, the burden of proof is reversed so that the entrepreneur must prove that his activity will not cause pollution or damage to the environment. ${ }^{9}$ In the environmental liability cases, there is no need to prove the fault of the polluter; only damage and causation need be proved. ${ }^{10}$ Regarding governance, in "Mensalão" several politicians and executives were sentenced by the Judiciary and convicted of

7 Brazil Constitution of 1988.

8 See the jurisprudence of the Superior Court of Justice. Case REsp $1237893<$ www.stj.jus.br/sites/STJ> accessed1 May 2016.

9 ibidCase REsp 38356.

10 ibidCase REsp 1374284. 
criminal practices. ${ }^{11}$ In "Operation Car Wash" politicians and contractors were arrested on suspicion of corruption crimes and will soon be judged. ${ }^{12}$

Evidently, the approach of the Brazilian judiciary is to exercise judicial activism and an expansive interpretation of the law to sanction or stop projects, actions or policies that pollute water and soil and threaten the animals, plants or human health. This approach aligns with the primordial roles of the judiciary, ubijusibiremedium, where there is a wrong; the judiciary will provide environmental remedies and protection to the common citizen

\section{CONCLUSION}

According to the principle of Separation of Powers coined by Montesquieu in his classic work "De l'esprit des lois", the judge should only be the "la bouche de la loi" (the mouth of the law). However, in Brazil the Judicial Branch is exercising judicial activism to promote environmental, social, economic, and, in particular, governance aspects of sustainable development. This approach requires a pragmatic understanding and application of the law to ensure that unsustainable actions, projects or policies that could result in environmental degradation are scrutinised within the borders of applicable laws and policies.

11 Vinod Sreeharsha, "Brazilian Senator and Banker Are Arrested as Petrobras Scandal Widens" The New York Times(25 November 2015) < www.nytimes.com/ 2015/11/26/world/americas/brazil-corruption-petrobas.html> accessed2 May 2016.

12 Dan Horch, "Corruption Scandal at Petrobras Threatens Brazil's Economy" The New York Times (11 February 2015) < http://dealbook.nytimes.com/2015/ 02/11/a-corruption-scandal-at-petrobras-threatens-brazils-bond-market-andeconomy/?_r=0> accessed 1 May 2016. 